\title{
EFEKTIVITAS PSG PADA DUDI KEAHLIAN AKUNTANSI SMK NEGERI 7 DAN SMK MUHAMMADIYAH 2 YOGYAKARTA
}

\author{
Surya Jatmika \\ Prodi Pendidikan Akuntansi Universitas Negeri Yogyakarta \\ suryajatmika026@gmail.com \\ Diana Rahmawati \\ Jurusan Pendidikan Akuntansi Universitas Negeri Yogyakarta
}

\begin{abstract}
Abstrak
Penelitian ini adalah penelitian deskriptif kuantitatif yang memiliki empat tujuan yaitu bertujuan mendeskripsikan pelaksanaan PSG pada DUDI, mengetahui tingkat efektivitas pelaksanaan PSG, mengetahui faktor pendukung dan penghambat efektivitas pelaksanaan PSG pada DUDI, mengetahui pola pelaksanaan PSG yang ideal pada DUDI. Metode pengumpulan data yang digunakan adalah dokumentasi, angket, wawancara, observasi langsung, dan triangulasi. Berdasarkan hasil penelitian diketahui pelaksanaan seluruh komponen PSG telah sesuai dengan ketentuan penyelenggaraan PSG. Efektivitas pelaksanaan PSG Jurusan Akuntansi SMK Negeri 7 ditinjau dari keterlaksanaan seluruh komponennya adalah sangat efektif dengan persentase keterlaksanaan 83\%. Untuk SMK Muhammadiyah 2 efektivitasnya adalah efektif dengan persentase keterlaksanaan $75,4 \%$. Faktor pendukung pelaksanaan PSG Jurusan Akuntansi SMK Negeri 7: kesadaran dari siswa, fasilitas sekolah, kesadaran dari guru, dari segi biaya, dan hubungan sekolah dengan industri yang baik. Faktor pendukung PSG SMK Muhammadiyah 2: pembekalan terhadap siswa yang akan prakerin, masukan dari DUDI, pembimbing, dan kesesuaian tempat prakerin dengan kompetensi siswa. Faktor penghambat pelaksanaan PSG Jurusan Akuntansi SMK Negeri 7: tidak semua dunia industri sebagai tempat prakerin pekerjaannya sesuai dengan kompetensi siswa, karakter siswa, dan insentif pembimbing yang masih kurang. Faktor penghambat pelaksanaan PSG SMK Muhammadiyah 2: karakter siswa, masih ada frekuensi pemantauan dan kreativitas dari pembimbing yang kurang, kebijakan institusi keuangan, prosedur pencatatan akuntansi di IP sudah tidak manual, dan kurang adanya transparansi sekolah kepada Komite Sekolah. Pola pelaksanaan PSG yang ideal pada DUDI SMK Negeri 7 dan SMK Muhammadiyah 2 Yogyakarta perlu ditingkatkan pada pola pelaksanaan PSG model 2.
\end{abstract}

Kata kunci: PSG, Efektivitas, Pendukung, Penghambat, Pola Pelaksanaan

\begin{abstract}
This research is descriptive quantitative. It has four objectives that aim to describe the implementation of the PSG on DUDI, knowing the effectiveness of implementation PSG, find out the factors supporting and inhibiting of effectiveness implementation PSG on DUDI, knowing the model of PSG ideal execution on DUDI. Data collection methods used are documentation, questionnaires, interviews, direct observation, and triangulation. Based on the research results revealed the implementation of all components in accordance with the provisions PSG implementation. The effectiveness of implementation PSG Accounting Department SMK 7 in terms of adherence to all the components is very effective with the percentage of adherence to $83 \%$. The effectiveness PSG SMK Muhammadiyah 2 is effective with percentage adherence to $75.4 \%$. The supporting factors PSG SMK 7: awareness of
\end{abstract}


students, school facilities, the awareness of teachers, in terms of cost, and good relationships between school and industry. The supporting factors PSG SMK Muhammadiyah 2: the briefing to the students who will prakerin, input from DUDI, mentor, and prakerin places conformity with the competence of students. The inhibiting factors of implementation PSG SMK 7: not all of the industries as place for prakerin are accordance with the competence student prakerin, the student's character, and mentor's incentives are still lacking. The inhibiting factors PSG SMK Muhammadiyah 2: the character of the students, the frequency of monitoring and supervising creativity mentors are still lack, financial institution policies, accounting records procedures at the IP isn't manual, and the school transparancy to the School Committee still lack. PSG ideal model implementation in DUDI SMK 7 and SMK Muhammadiyah 2 Yogyakarta needs to be improved on the model 2 of implementation PSG models.

Keyword: PSG, Effectiveness, Supports, Inhibitions, Implementation Model

\section{PENDAHULUAN}

Pada era globalisasi dan informasi, kemampuan SDM dalam penguasaan ilmu pengetahuan dan teknologi (IPTEK) bukan hanya merupakan kebutuhan, tetapi sudah menjadi keharusan. Apabila bangsa Indonesia ingin berperan dalam persaingan global, sudah selayaknya bangsa Indonesia harus menyikapi kondisi tersebut dengan program yang berorientasi pada percepatan peningkatan mutu pendidikan atau kualitas SDM Indonesia. Salah satunya melalui program kemitraan antara pemerintah daerah, dunia pendidikan (SMK), dunia usaha dan industri (DUDI) dalam rangka terlaksananya link and match (keterkaitan dan kesepadanan) antara dunia pendidikan dengan dunia usaha dan industri. Bangsa Indonesia membutuhkan upaya nyata untuk mewujudkan dan membangun "suasana sinergis" dalam menyiapkan tenaga kerja yang siap bersaing dalam era globalisasi.
Pendidikan sistem ganda (PSG) adalah salah satu strategi pokok dalam rangka operasionalisasi "link and match" di mana suatu proses pendidikan yang melibatkan sekolah satu sisi dan industri pada sisi lain. Melalui penerapan pendidikan sistem ganda ini, diharapkan kesenjangan kualitas lulusan sekolah teknologi dengan kebutuhan kualitas tenaga kerja oleh industri dapat ditekan. Dewasa ini pendidikan sistem ganda digunakan sebagai salah satu upaya untuk mempersiapkan tenaga-tenaga profesional yang siap pakai sesuai dengan kebutuhan berbagai sektor perekonomian (Sutrisno, 1996).

(2004) bahwa selama ini disinyalir
terdapat hubungan yang kurang baik antara pendidikan dengan ketenagakerjaan. Hubungan yang kurang baik tersebut di antaranya adalah semakin meningkatnya tingkat pengangguran secara umum dan 
pengangguran terdidik secara khusus, tidak sesuainya antara latar belakang pendidikan dengan bidang pekerjaan yang dilakukan, rendahnya produktivitas tenaga kerja, dan kurang relevannya pengetahuan dan keterampilan yang diberikan kepada anak didik dengan pengetahuan dan keterampilan yang dibutuhkan dalam dunia kerja.

Disnakertrans DIY, Dwi Santosa dalam harianjogja.com melansir, jumlah pengangguran di DIY saat ini berdasar data terakhir Desember 2011 mencapai hingga 127.000 orang. Pengangguran paling banyak ternyata adalah lulusan SMK sebanyak 22.547 orang, disusul lulusan SMA sebanyak 19.491 orang serta tamatan perguruan tinggi sebanyak 11.338 penganggur (Harianjogja.com, 8 Oktober 2012). Berdasarkan data Dinas Sosial Tenaga Kerja dan Transmigrasi (Dinsosnakertrans) Kota Yogyakarta, di Kota Yogyakarta jumlah penganggur mencapai 17.481 orang atau turun dari 2011 yang mencapai 18.241 orang. Dari jumlah pengangguran tersebut terbanyak lulusan SMA/SMK sebanyak 8.949 orang. Disusul lulusan SMP 3.794 orang, lulusan Sarjana 2.973 orang dan lulusan SD 1.765 orang (Republika.co.id, 10 Februari 2013).

Data-data pengangguran tersebut mengemukakan bahwa tamatan SMK merupakan jumlah yang terbanyak maka dapat ditarik kesimpulan bahwa persepsipersepsi mengenai adanya hubungan yang kurang baik antara pendidikan dengan dunia ketenagakerjaan dapat menjadi faktor terjadinya permasalahan tersebut. Tujuan pelaksanaan PSG oleh SMK memiliki peran untuk menghasilkan peserta didik yang kompeten sesuai dengan bidang keahlian kejuruan yang dipilih, sesuai dengan tuntutan dunia kerja dan juga peran SMK sebagai penghubung antara dunia pendidikan dengan dunia usaha maupun dunia industri belum dapat dijalankan secara optimal. Akibat tujuan SMK melalui pelaksanaan PSG tidak tercapai, maka memicu terjadinya kesenjangan antara harapan dunia pendidikan dengan tuntutan dunia usaha maupun dunia industri. Kerjasama antara SMK dengan dunia usaha maupun dunia industri dalam menghasilkan PSG perlu dipertanyakan keberlangsungannya (sustainability).

SMK Negeri 7 Yogyakarta dan SMK Muhammadiyah 2 Yogyakarta merupakan salah satu SMK Negeri dan Swasta di Kota Yogyakarta yang memiliki program keahlian akuntansi. Sekolah negeri dengan sekolah swasta memiliki perbedaan. Ada beberapa faktor yang menjadi pembeda antara sekolah negeri dengan sekolah swasta antara lain tingkat perhatian dan perlakuan guru terhadap 
murid di kelas, guru atau pengajar, pola pengajaran, cara belajar, persepsi masyarakat, gengsi orang tua, kualitas output, jumlah murid, sarana dan prasarana, serta status dari sekolah tersebut. Adanya perbedaan-perbedaan tersebut tentunya akan mempengaruhi efektivitas program PSG yang dilaksanakan oleh masing-masing SMK.

Sebagai sekolah kejuruan baik SMKN 7 Yogyakarta maupun SMK Muhammadiyah 2 Yogyakarta, tentu lulusan-lulusannya dapat langsung bekerja di dunia usaha dan industri. Kesuksesan sekolah kejuruan dalam menjadikan lulusan-lulusannya mendapat pekerjaan, tentu tidak terlepas dari hubungan antara sekolah dengan DUDI. Kota Yogyakarta merupakan ibu kota dari Daerah Istimewa Yogyakarta (DIY) memiliki banyak sekali perusahaan dan industri. Kota Yogyakarta seharusnya menjadi barometer kesinambungan antara dunia pendidikan dengan dunia ketenagakerjaan dibandingkan dengan daerah-daerah lain di DIY. Tetapi fakta di lapangan menunjukkan fenomena yang berbeda, tingginya angka pengangguran di DIY maupun Kota Yogyakarta, yang ternyata lebih banyak jumlah tamatan SMK yang menganggur maka hal inilah yang membuat peneliti merasa perlu untuk melakukan pengkajian kembali efektivitas dari penerapan PSG yang dilakukan oleh SMK, terutama SMK yang memiliki program keahlian akuntansi karena disesuaikan juga dengan background pendidikan peneliti yang menempuh jurusan Pendidikan Akuntansi. Di samping prihatin dengan data jumlah pengangguran dari jenjang SMK, alasan peneliti melakukan penelitian mengenai efektivitas penerapan PSG di SMK adalah karena sepanjang pengetahuan peneliti dan juga pencarian peneliti melalui google scholar yang berisi jurnal-jurnal baik nasional maupun internasional, sampai saat ini belum ada hasil penelitian mengenai efektivitas penerapan PSG oleh SMK terutama khusus meneliti program keahlian Akuntansi. Dengan berbagai alasan di atas, peneliti memilih meneliti mengenai "Studi Efektivitas Implementasi Program Pendidikan Sistem Ganda (PSG) Pada Dunia Usaha dan Dunia Industri (DUDI) Bidang Keahlian Akuntansi SMK Negeri 7 Yogyakarta dan SMK Muhammadiyah 2 Yogyakarta." Diharapkan nantinya hasil penelitian ini dapat menjadi acuan untuk mengkaji kembali efektivitas penerapan PSG di SMK saat ini.

\section{METODE}

\section{Desain Penelitian}

Jenis penelitian ini menurut pendekatannya merupakan penelitian 
deskriptif kuantitatif. Dalam penelitian ini, penelitian deskriptif digunakan untuk menjelaskan mengenai pelaksanaan PSG pada DUDI Bidang Keahlian Akuntansi SMK Negeri 7 Yogyakarta dan SMK Muhammadiyah 2 Yogyakarta, sedangkan penelitian kuantitatif digunakan untuk mengetahui tingkatan efektivitas pelaksanaan PSG pada DUDI Bidang Keahlian Akuntansi SMK Negeri 7 Yogyakarta dan SMK Muhammadiyah 2 Yogyakarta.

\section{Subjek dan Objek Penelitian}

Subjek dari penelitian ini adalah Kepala Sekolah SMK, Ketua Majelis Sekolah (Komite Sekolah), Ketua Pokja Kurikulum, Ketua Pokja Prakerin, dan Perwakilan Industri Pasangan. Objek penelitian ini ada tujuh hal, yaitu Program Diklat, Sumber Daya Manusia, Fasilitas Pendidikan, Manajemen Pendidikan, Siswa, Biaya, dan Institusi Pasangan.

\section{Prosedur Penelitian}

Prosedur penelitiannya terdiri dari lima tahapan, yaitu: Pertama, persiapan instrumen penelitian, pada tahapan ini peneliti menyiapkan alat maupun instrumen penelitian yang akan digunakan untuk mengumpulkan data, seperti: angket tertutup dan pedoman wawancara. Kedua, pengumpulan data, pada tahap ini peneliti mengambil atau mengumpulkan data-data melalui angket tertutup, wawancara mendalam, maupun dokumen, serta observasi hal-hal yang berkaitan dengan pelaksanaan PSG yang ada di SMKN 7 Yogyakarta dan SMK Muhammadiyah 2 Yogyakarta. Ketiga, reduksi data, pada tahap ini peneliti merangkum, memilih hal-hal yang pokok, memfokuskan pada hal-hal yang penting, dan membuang yang tidak perlu dari hasil pengumpulan data. Keempat, analisis data, pada tahap ini peneliti melakukan uji sumbangan efektivitas masing-masing komponen dalam PSG dan dilakukan juga uji efektivitas pelaksanaan pendidikan sistem ganda untuk mengolah data yang telah dikumpulkan baik dari angket tertutup, wawancara, dokumentasi, sserta observasi yang telah direduksi dari tahapan-tahapan sebelumnya. Kelima, penarikan kesimpulan dan pembuatan laporan penelitian, pada tahap ini peneliti melakukan penarikan kesimpulan dari hasil analisis data yang dilakukan dan dilanjutkan pada pembuatan laporan hasil penelitian.

\section{Teknik Pengumpulan Data dan} Instrumen

Teknik pengumpulan data yang digunakan dalam penelitian ini adalah dokumentasi, angket, wawancara, 
observasi langsung, dan triangulasi. Dokumentasi digunakan untuk mengumpulkan data mengenai struktur organisasi, arsip-arsip surat kegiatan dalam pelaksanaan pendidikan sistem ganda, dan data tentang hasil uji kompetensi tahun sebelumnya bagi siswa yang praktik industri. Angket digunakan untuk memperoleh data tentang tingkat efektivitas pelaksanaan pendidikan sistem ganda.

Wawancara dalam penelitian ini digunakan untuk memperoleh data mengenai pelaksanaan pendidikan sistem ganda serta faktor-faktor pendukung dan penghambatnya. digunakan untuk meluruskan data yang masih meragukan maupun untuk keperluan validasi data terutama informasi sarana dan prasarana praktik yang tersedia. Triangulasi merupakan teknik pengumpulan data yang bersifat menggabungkan dari berbagai teknik pengumpulan data dan sumber data yang telah ada.

\section{Teknik Analisis Data}

Analisis data dalam penelitian ini terdiri dari beberapa tahap, yaitu analisis data angket, analisis data wawancara, analisis data studi dokumentasi, dan analisis data hasil observasi langsung. Analisis wawancara, observasi, dan dokumentasi dilakukan saat proses pengambilan data langsung, yaitu saat peneliti berada di lapangan. Proses analisis data dilakukan dengan mereduksi jawaban responden dan mengkategorikan sesuai dengan pedoman yang telah dibuat.

Analisis angket tertutup dilakukan setelah angket terkumpul kembali kemudian dianalisis secara deskriptif kualitatif dengan persentase. Selanjutnya menentukan sumbangan efektif dari penyelenggaraan tiap-tiap komponen program PSG (Nk Kn) dan keberhasilan penyelenggaraan dari program PSG (Nk PSG) dihitung berdasarkan rumus:

a. Uji Sumbangan Efektivitas Masing-

Masing Komponen PSG

Dengan Rumus:

$$
\begin{aligned}
& N k \text { Kn } \\
& =\frac{\sum S T E n+\sum T E n+\sum C E n+\sum E n+\sum S E n}{\sum S k o r \text { Max }} \times 100 \%
\end{aligned}
$$$$
\sum \text { Skor Max }=\sum N \times 5
$$

(Dikmenjur, 1997: 7)

b. Uji Efektivitas Pelaksanaan Pendidikan Sistem Ganda

Dengan rumus:

NkPSG

$=\frac{\sum T E+\sum K E+\sum C E+\sum E+\sum S E}{\sum S k o r \operatorname{Max}} \times 100 \%$

$\sum S k o r \operatorname{Max}=\sum N \times 5$

(Dikmenjur, 1997: 7)

Penentuan tingkat efektivitas dari setiap hasil perhitungan rumus-rumus di atas, menggunakan ketentuan rentang nilai efektivitas keberhasilan PSG berdasarkan 
Jurnal Pendidikan Akuntansi Indonesia, Vol. XII, No. 1, Tahun 2014

Surya Jatmika \& Diana Rahmawati

$48-63$

pada nilai keberhasilan PSG menurut

Dikmenjur (1997: 7) sebagaimana disajikan pada tabel 1 .

Tabel 1. Rentang Nilai Efektivitas:

\begin{tabular}{cc}
\hline Nilai (\%) & Predikat \\
\hline $81-100$ & Sangat Efektif \\
$61-80$ & Efektif \\
$41-60$ & Cukup Efektif \\
$21-40$ & Tidak Efektif \\
$00-20$ & Sangat Tidak Efektif
\end{tabular}

HASIL DAN PEMBAHASAN

Pelaksanaan PSG Pada Institusi

Pasangan (IP) SMK Negeri 7

Yogyakarta

Berdasarkan hasil deskripsi data pelaksanaan PSG pada IP Jurusan Akuntansi SMK Negeri 7 Yogyakarta diperoleh dari wawancara terhadap responden yang sudah ditetapkan dalam penelitian ini. Pada pelaksanaan wawancara diungkap pelaksanaan dari masing-masing komponen PSG meliputi komponen program diklat, komponen sumber daya manusia, komponen fasilitas pendidikan, komponen manajemen pendidikan, komponen siswa, komponen biaya, dan komponen IP (dalam penelitian ini IP PSG SMK Negeri 7 Yogyakarta adalah KAP (Kantor Akuntan Publik) Inaresjz Kemalawarta).
Tabel 2. Ringkasan Pelaksanaan PSG pada $\begin{array}{llll}\text { IP Jurusan Akuntansi SMKN } 7 & \text { SMN }\end{array}$ Yogyakarta

Komponen Pelaksanaan PSG

PSG

\begin{tabular}{ll}
\hline Program & 1. KBM di SMK \\
Diklat & disesuaikan dengan apa \\
& yang akan diberikan di IP \\
& (Institusi Pasangan). \\
2. & Sekolah telah melakukan \\
& sinkronisasi kompetensi \\
& dengan DUDI.
\end{tabular}

3. Materi Program Diklat disesuaikan dengan spektrum keahlian.

4. Materi Teori Kejuruan diberikan di sekolah, Materi Praktik Dasar Kejuruan dan Praktik Keahlian Produktif diberikan di sekolah dan di industri.

5. Sebelum prakerin sekolah dengan DUDI berdiskusi mengenai programprogram/kegiatan yang akan dilaksanakan dalam prakerin.

SDM 1. Rasionalisasi peta guru dengan jumlah siswa sudah baik. 
2. Peningkatan kemampuan guru dilakukan melalui diklat-diklat yang diselenggarakan oleh pemerintah, MGMP, maupun KKG. Pendidikan laboratorium Akuntansi sendiri.

2. Sekolah memiliki unit bussiness centre seperti minimarket, bank mini, usaha ticketing dan koperasi yang menunjang peningkatan kemampuan siswa.

3. Sekolah menyediakan pembimbing bagi siswa prakerin.

4. IP menyediakan instruktur untuk siswa prakerin serta peralatan kerja seperti komputer, laptop, LCD, meja, kursi, dsb.

5. Siswa diberikan pengarahan sebelum prakerin di IP.

6. Penilaian siswa prakerin sesuai dengan blangko penilaian yang diberikan pihak sekolah.

Manajemen
Pendidikan

dipantau secara rutin baik

mengajar maupun

administrasi

pembelajarannya.

2. Monitoring dilakukan minimal satu kali dalam satu tahun, diharapkan bisa dua kali sekaligus supervisi.

3. Prosedur monitoring prakerin dilakukan oleh guru pembimbing yang sudah dibagi oleh KK (Ketua Kompetensi) Akuntansi.

4. Uji Kompetensi dilakukan di sekolah.

5. Komite Sekolah dilibatkan ketika kunjungan memantau prakerin siswa.

6. Pemasaran tamatan dilakukan melalui proses negosiasi dengan DUDI.

7. Pemantauan tamatan dilakukan oleh BKK.

Siswa

1. Siswa mendapatkan pembekalan selama dua hari sebelum penerjunan prakerin.

2. Pelaksanaan prakerin dilakukan selama tiga bulan yaitu bulan 
November-Februari.

3. Proses penempatan siswa dilakukan oleh $\mathrm{KK}$ masing-masing Jurusan.

4. Proses seleksi tidak ada, kecuali bagi perusahaan (IP) dengan permintaanpermintaan khusus.

5. Daya tampung prakerin Akuntansi terdapat 19 Perusahaan (IP).

Biaya 1. Biaya disusun dalam RKAS (Rencana Kegiatan Anggaran Sekolah) dan keseluruhan biaya masuk pada RAPBS (Rencana Anggaran Pembelanjaan Biaya Sekolah).

2. Biaya prakerin keseluruhan sudah ditanggung pemerintah (APBD) dan hanya menggunakan sedikit Dana Masyarakat (SPP Siswa).

Institusi

1. Sekolah

membuat

Pasangan checklist kelayakan tempat prakerin dalam validasi dan sinkronisasi IP.

2. Naskah kerjasama sudah diterbitkan pada 10 perusahaan.

3. Poin-poin kerjasama terdiri dari MoU prakerin, apabila ada lowongan kerja memberitahu sekolah, dapat digunakan sebagai tempat OJT guru, dan dapat digunakan sebagai tempat uji kompetensi.

Pelaksanaan PSG Pada IP SMK Muhammadiyah 2 Yogyakarta

Deskripsi data pelaksanaan PSG pada IP Jurusan Akuntansi SMK Muhammadiyah 2 Yogyakarta diperoleh dari wawancara terhadap responden yang sudah ditetapkan dalam penelitian ini. Pada pelaksanaan wawancara diungkap pelaksanaan dari masing-masing komponen PSG, meliputi komponen program diklat, komponen sumber daya manusia, komponen fasilitas pendidikan, komponen manajemen pendidikan, komponen siswa, komponen biaya, dan komponen IP (dalam penelitian ini IP PSG SMK Muhammadiyah 2 Yogyakarta adalah Bank BPR Syariah Bangun Drajat Warga). 
Tabel 3. Ringkasan Hasil Pelaksanaan PSG pada IP Jurusan Akuntansi SMK Muhammadiyah 2 Yogyakarta

\begin{tabular}{ll}
\hline $\begin{array}{l}\text { Komponen } \\
\text { PSG }\end{array}$ & Pelaksanaan PSG \\
\hline Program & 1. \\
Diklat & dilakukanan dengan \\
& memberikan \\
& materi-materi \\
& sesuai Institusi \\
& Pasangan pada \\
& prakerin.
\end{tabular}

2. Proses validasi dan sinkronisasi Program Diklat dilakukan dengan adanya masukanmasukan dari DUDI.

3. Pelaksanaan prakerin biasanya siswa memiliki kerjasama dengan perusahaan dan sekolah membuat surat permohonan kerjasama.

4. Materi Teori Kejuruan, Praktik Dasar Kejuruan, dan Praktik

Keahlian Produktif

diberikan di sekolah.

SDM

1. Rasionalisasi peta guru disesuaikan dengan kompetensi masing-masing guru.

2. Peningkatan kemampuan dilakukan melalui kegiatan lokakarya (kunjungan industri) dan diklat-diklat.

Fasilitas

Pendidikan

1. SMK belum

mempunyai laboratorium Akuntansi sendiri, padahal jurusan lain sudah.

2. Sekolah menyediakan pembimbing dalam pelaksanaan prakerin.

3. Institusi Pasangan (IP) menyediakan instruktur dalam prakerin, peralatan kerja seperti komputer, arsip 


\begin{tabular}{|c|c|c|c|}
\hline & transaksi, dsb & & langsung dalam \\
\hline & sudah tersedia & & pemantauan \\
\hline & pada IP. & & prakerin. \\
\hline & 4. IP pada awal & & 5. Pemasaran tamatan \\
\hline & prakerin, & & dilakukan dengan \\
\hline & melakukan & & memanfaatkan \\
\hline & orientasi pada & & jaringan alumni. \\
\hline & siswa mengenai & Siswa & 1. Sehari sebelum \\
\hline & kondisi IP. & & penerjunan \\
\hline & 5. Penilaian siswa & & prakerin siswa \\
\hline & prakerin mengikuti & & diberikan \\
\hline & form penilaian & & pembekalan. \\
\hline & yang disediakan & & 2. Pelaksanaan \\
\hline & sekolah. & & prakerin \\
\hline Manajemen & 1. Monitoring KBM & & tergantung pada IP \\
\hline Pendidikan & dilakukan secara & & dalam kapan bisa \\
\hline & rutin, minimal dua & & menerima para \\
\hline & kali dalam satu & & siswa prakerin, \\
\hline & tahun. & & biasanya untuk \\
\hline & 2. Monitoring & & Akuntansi \\
\hline & prakerin dilakukan & & dilakukan pada \\
\hline & dengan & & bulan Febuari- \\
\hline & pembimbing & & April. \\
\hline & mendatangi siswa & & 3. Proses penempatan \\
\hline & secara berkala & & siswa prakerin \\
\hline & pada waktu & & dilakukan oleh \\
\hline & prakerin. & & Waka Humas \\
\hline & 3. Ujian evaluasi & & SMK. \\
\hline & prakerin & & 4. Proses seleksi \\
\hline & dilaksanakan di & & siswa tidak ada. \\
\hline & sekolah. & & 5. Daya tampung \\
\hline & 4. Komite Sekolah & & maksimal tiap IP \\
\hline & tidak dilibatkan & & adalah enam siswa \\
\hline
\end{tabular}




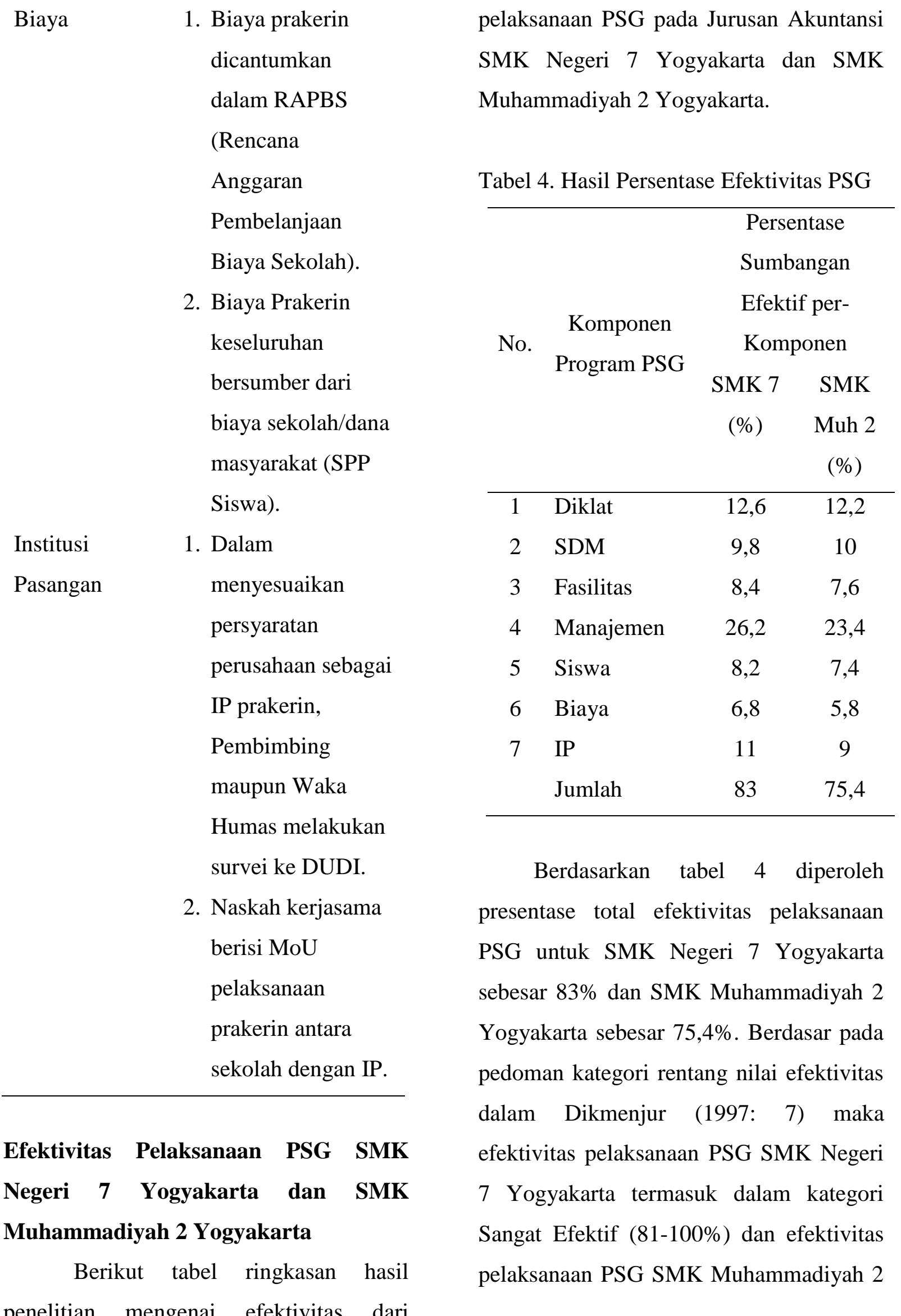


Yogyakarta termasuk dalam kategori Efektif (61-80\%).

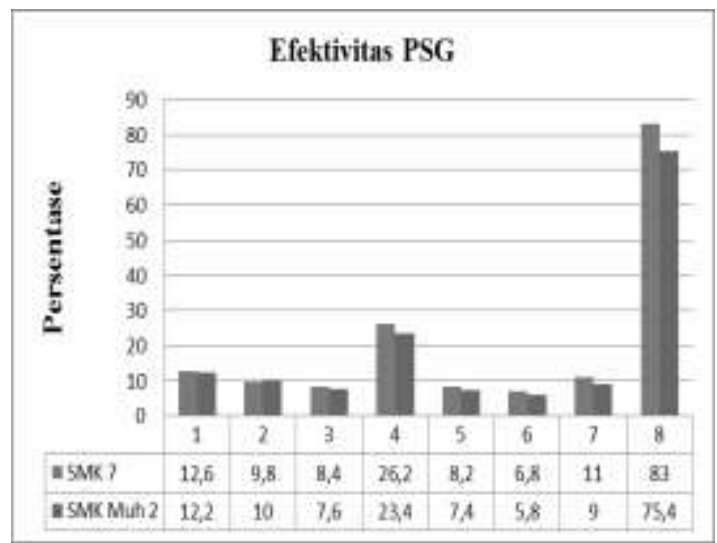

Gambar 1. Grafik Ringkasan Hasil Persentase Efektivitas PSG

\section{Faktor Pendukung dan Penghambat dalam Pelaksanaan PSG pada IP Jurusan Akuntansi SMK Negeri 7 Yogyakarta}

Faktor-faktor pendukung pelaksanaan PSG pada IP Jurusan Akuntansi SMK Negeri 7 Yogyakarta, yaitu kesadaran dari siswa, fasilitas sekolah, kesadaran dari guru, dari segi biaya, dan adanya kerjasama/hubungan sekolah dengan industri yang baik.

Faktor-faktor penghambat pelaksanaan PSG pada IP Jurusan Akuntansi SMK Negeri 7 Yogyakarta, yaitu tidak semua dunia industri yang digunakan sebagai tempat prakerin pekerjaannya sesuai dengan kompetensi yang sekolah sodorkan, dari karakter siswa, dan insentif untuk pembimbing yang masih kurang.
Faktor Pendukung dan Penghambat dalam Pelaksanaan PSG pada IP Jurusan Akuntansi $\quad$ SMK Muhammadiyah 2 Yogyakarta

Faktor-faktor pendukung pelaksanaan PSG pada IP Jurusan Akuntansi SMK Muhammadiyah 2 Yogyakarta, yaitu pemberian pembekalan terhadap siswa yang akan melaksanakan prakerin, adanya masukan-masukan dari DUDI, pembimbing, dan kesesuaian tempat prakerin dengan kompetensi siswa.

Faktor-faktor penghambat pelaksanaan PSG pada IP Jurusan Akuntansi SMK Muhammadiyah 2 Yogyakarta, yaitu karakter siswa, masih ada frekuensi pemantauan pembimbing dan kreativitas dari pembimbing yang kurang, kebijakan institusi keuangan, institusi pasangan prosedur pencatatan akuntansi keuangannya sudah tidak manual, dan kurang adanya transparansi sekolah kepada Komite Sekolah.

Pola yang Ideal dalam Pelaksanaan PSG pada IP Jurusan Akuntansi SMK $\begin{array}{lllll}\text { Negeri } & 7 & \text { Yogyakarta dan } & \text { SMK }\end{array}$ Muhammadiyah 2 Yogyakarta

Berdasarkan pertimbangan deskripsi data yang didapatkan, pola pelaksanaan PSG pada IP SMK Negeri 7 Yogyakarta dan SMK Muhammadiyah 
dari pelaksanaan model 1 sudah selayaknya ditingkatkan pada model 2 . Model 2 merupakan pola pelaksanaan PSG yang lebih baik dari model 1 (peningkatan dari model 1).

\begin{tabular}{|c|c|c|}
\hline \multicolumn{3}{|c|}{ Model 2 } \\
\hline Kelas I & Kelas II & Kelas III \\
\hline$(1)$ & $(1)$ & $(1)$ \\
\hline$(2)$ & $(2)$ & $(3 b)$ \\
\hline$(3 a)$ & $(3 a)$ & \multirow{2}{*}{$(3 c)$} \\
\hline$(3 b)$ & $(3 b)$ & \\
\hline
\end{tabular}

Gambar 2. Model 2 Pelaksanaan PSG

Ditinjau dari segi persyaratan perusahaan sebagai IP dalam PSG pada kedua sekolah dapat dikatakan telah memenuhi persyaratan. Persyaratan yang dimaksud meliputi adanya tempat dan peralatan kerja yang memadai, tersedianya tenaga kerja instruktur, adanya heterogenitas kegiatan di IP dengan kompetensi yang disyaratkan dalam kurikulum program diklat, adanya kontinuitas kegiatan produksi pada IP mendukung pelaksanaan prakerin pada IP.

Dalam penerapan pola pelaksanaan PSG model II ini, keterlibatan IP telah dimulai pada tahun kedua dan tahun ketiga untuk menangani pembekalan kemampuan dasar kejuruan (selama tiga bulan efektif) dan pembekalan kemampuan praktik produktif dilaksanakan pada tahun ketiga. Pemilihan pola KBM di IP dapat dilakukan dengan kombinasi model penyelenggaraan Block Release dengan Day Release maupun Hour Release.

\section{SIMPULAN DAN SARAN}

\section{Simpulan}

Berdasarkan hasil dari penelitian dan pembahasan dapat disimpulkan bahwa:

1. Pelaksanaan PSG pada IP Jurusan Akuntansi SMK Negeri 7 Yogyakarta dan SMK Muhammadiyah 2 Yogyakarta ditinjau dari pelaksanaan seluruh komponen PSG pada umumnya sesuai dengan ketentuan penyelenggaraan PSG yang tercantum dalam Kep. Mendikbud No. 323/U/1997 maupun pedoman pelaksanaan PSG Dikmenjur 1997.

2. Efektivitas pelaksanaan PSG pada IP Jurusan Akuntansi SMK Negeri 7 Yogyakarta ditinjau dari keterlaksanaan seluruh komponennya adalah sangat efektif dengan persentase keterlaksanaan $\quad 83 \%$. Efektivitas pelaksanaan PSG pada IP Jurusan Akuntansi SMK Muhammadiyah 2 Yogyakarta ditinjau dari keterlaksanaan seluruh komponennya adalah efektif dengan persentase keterlaksanaan $75,4 \%$.

3. Faktor-faktor pendukung pelaksanaan PSG pada IP Jurusan Akuntansi SMK 
Negeri 7 Yogyakarta, yaitu kesadaran dari siswa, fasilitas sekolah, kesadaran dari guru, dari segi biaya, dan adanya kerjasama/hubungan sekolah dengan industri yang baik. Faktor-faktor pendukung pelaksanaan PSG pada IP Jurusan Akuntansi SMK Muhammadiyah 2 Yogyakarta, yaitu pemberian pembekalan terhadap siswa yang akan melaksanakan prakerin, adanya masukan-masukan dari DUDI, pembimbing, dan kesesuaian tempat prakerin dengan kompetensi siswa. Faktor-faktor penghambat pelaksanaan PSG pada IP Jurusan Akuntansi SMK Negeri 7 Yogyakarta, yaitu tidak semua dunia industri yang digunakan sebagai tempat prakerin pekerjaannya sesuai dengan kompetensi yang sekolah sodorkan, dari karakter siswa, dan insentif untuk pembimbing yang masih kurang. Faktor-faktor penghambat pelaksanaan PSG pada IP Jurusan Akuntansi SMK Muhammadiyah 2 Yogyakarta, yaitu karakter siswa, masih ada frekuensi pemantauan pembimbing dan kreativitas dari pembimbing yang kurang, kebijakan institusi keuangan, institusi pasangan prosedur pencatatan akuntansi keuangannya sudah tidak manual, dan kurang adanya transparansi sekolah kepada Komite Sekolah.
4. Pola pelaksanaan PSG pada IP Jurusan Akuntansi SMK Negeri 7 Yogyakarta dan SMK Muhammadiyah 2 Yogyakarta selama ini adalah model 1 perlu ditingkatkan pada pola pelaksanaan PSG model 2.

\section{Saran}

Berdasarkan deskripsi data, pembahasan dan kesimpulan dari penelitian ini, maka saran yang diberikan kepada kedua SMK adalah:

1. Sekolah perlu melakukan pendekatan dengan mengirimkan guru atau karyawan yang ada dalam SMK ke DUDI untuk melakukan sosialisasi program Diklat maupun sosialisasi mengenai program PSG yang ada di SMK pada DUDI maupun instruktur yang ada pada DUDI, sehingga nantinya akan tercipta kesepahaman dan keterbukaan antara DUDI maupun SMK.

2. Perlu peningkatan perhatian dan keterbukaan dari pembimbing maupun instruktur dalam menghadapi permasalahan siswa prakerin.

3. Penilaian prakerin sebaiknya harus dapat diukur tidak hanya berwujud kata-kata (Baik, Cukup Baik, dsb) tetapi ada korelasinya dengan rentang nilai yang sesuai tingkatan hasil belajar dalam wujud angka atau dapat juga 
seperti indeks prestasi.

4. Sekolah perlu menyelenggarakan uji sertifikasi profesi siswa secara komprehensif dengan melibatkan lembaga asosiasi profesi akuntansi (IAI) yang dengan adanya pengakuan dari asosiasi profesi tersebut sertifikat hasil ujian profesi dapat digunakan siswa untuk bersaing pada dunia ketenagakerjaan.

5. Peningkatan kesadaran para pembimbing dalam pentingnya peran monitoring maupun evaluasi dalam menunjang keterlaksanaan efektivitas program PSG yang dilakukan SMK.

6. Sekolah perlu meningkatkan keterbukaan (transparansi) dan meningkatkan keterlibatan komite sekolah dalam setiap proses pelaksanaan PSG.

7. Perlu adanya transparansi biaya prakerin sebagai wujud pertanggungjawaban penggunaan dana masyarakat terutama apabila terdapat penelitian mengenai hal tersebut.

8. Ditinjau dari segi persyaratan perusahaan sebagai IP dalam PSG dapat dikatakan telah memenuhi persyaratan. Pelaksanaan model I sudah selayaknya ditingkatkan pada model 2.

\section{DAFTAR PUSTAKA}

Depdiknas. (2003). Undang-Undang Nomor 20 tentang Sistem Pendidikan Nasional.

Dikmenjur. (1997). Monitoring dan Evaluasi Pendidikan Sistem Ganda. Jakarta: Dikmenjur Depdikbud.

Ghozali, Abbas. (2004). Peranan Pendidikan terhadap Pertumbuhan Ekonomi. Makalah disampaikan dalam Seminar Nasional Pendidikan oleh Fakultas Ilmu Pendidikan Universitas Mataram di Lombok, Nusa Tenggara Barat, tanggal 15 dan 16 September 2004.

Harian Jogja. (2012). Disnaker DIY Ribuan Penganggur Kebanyakan Lulusan SMK. Diakses dari http://www.harianjogja.com/baca/20 12/10/08/disnaker-diy-ribuanpenganggur-kebanyakan-lulusansmk-337012. Pada tanggal 15 Mei 2013.

Joko Sutrisno. (1996). Penerapan Pendidikan Sistem Ganda di Indonesia. Malang: PPPGT-VEDC

Republika. (2013). Kaum Terpelajar Dominasi Pengangguran di Yogyakarta. Diakses dari http://www.republika.co.id/berita/na sional/jawa-tengah-diynasional/13/02/10/mhzlff-kaumterpelajar-dominasi-penganggurandi-yogyakarta. Pada tanggal $10 \mathrm{Mei}$ 2013. 